\title{
Issues and Opportunities in Space Photovoltaics
}

Robert W. Francis and W.A. Somerville

The Aerospace Corporation

El Segundo, California

and

Dennis J. Flood

Lewis Research Center

Cleveland, Ohio

(NASA-TA-101425) ISSOES AND CEPOBTUNITIES

IA SPACE FHCTOVCLIAICS (NASA) 14 PCSCI 10B N89-15171
63/20 Unclas

Prepared for the

20th Photovoltaic Specialists Conference

sponsored by the Institute of Electrical and Electronics Engineers

Las Vegas, Nevada, September 26-30, 1988 
Robert $W$. Francis and W. A. Somerville THE AEROSPACE CORPORATION El Segundo, CA 90245-4691

and

Dennis J. Flood NASA LEWIS RESEARCH CENTER

Cleveland, OH 44135

\section{ABSTRACT}

Space power sources are becoming a central focus for determining man's potential and schedule for exploring and utilizing the benefits of space. The ability to search, probe, survey, and communicate chroughout our universe will depend on providing adequate power to the instruments that do these jobs. Power requirements for space platforms are increasing and will continue to increase into the twenty-first century. Photovoltaics have been a dependable power source for space for the last 30 years and have served as the primary source of power on virtually all DoD and NASA satellites. The performance of silicon (Si) solar cells has increased from $10 \%$ aif mass zero (AMO) solar energy conversion efficiency in the early 1960 's to almost $15 \%$ on today's spacecraft. Some technologists even think that the potential for solar photovoltaics has reached a plateau. However, present and near-future Air Force and NASA requirements show needs that, if the problems are looked upon as opportunities, can elevate the photovoltaic power source scientist and array structure engineer into the next technological photovoltaic growth curve.

\section{INTRODUCTION}

Technology development in solar photovoltaic devices and arrays is ongoing and progressing to higher efficiency solar cells and greater specific power levels, which will enable higher power electrical subsystems at reduced weight for spacecraft housekeeping and payload power. As such, solar photovoltaic arrays with electrochemical energy storage will be able to compete in both weight and cost effectiveness compared to upcoming alternative power technologies. Space power electrical subsystems based on solar photovoltaics have a theoretical maximum solar collection efficiency of $1353 \mathrm{~W} / \mathrm{m}^{2}$, which is the sun's irradiance in space above the earth's atmosphere. Issues in space solar photovoltaics are related to scientific and engineering problems associated with the most weight-eflicient and cost-effective method of converting this solar energy to electrical energy. Prnblems include higher device conversion efficiencies, tolerance to the natural charged-particle space irradiation environment, micrometeoroids, artificial threats, increased temperature stability, deployment and dynamic control of lerge upport structures, low atmospherle drag in low earth orbit, polnting and tracking requirements, and ground test qualification of large-area solar arrays.
The mainstay of space electrical power subsystems has been solar photovoltaic conversion with electrochemical energy storage provided by batteries. In the United States, most civilian and military space vehicles have used solar photovoltaic coupled with battery energy storage since the $1950^{\circ} \mathrm{s}$. Present block spacecraft designs are using or considering electrical power subsystems incorporating solar cells of eithe= 13 to $15 \%$ AMO silicon (Si) or 16 to $18 \%$ AMO solar energy conversion-efficient gallium arsenide (GaAs) in solar arrays with nickel-cadmium (NiCd) at $28 \mathrm{~W}-\mathrm{hr} / \mathrm{Kg}$ or nickel-hydrogen $\left(\mathrm{NiH}_{2}\right)$ at $40 \mathrm{~W}-\mathrm{hr} / \mathrm{Kg}$ batteries for energy storage in geosynchronous orbit to operate loads during eclipse. Technology planning activities for follow-on block designs, however, include thin, lightweight, single-junction ( $\mathrm{SJ}$ ) $\mathrm{Si}$ and GaAs solar cells and higher efficiency (greater than 20\%) multibandgap (MBG) solar cells, flexible, lightweight solar-array structures, and highenergy density sodium-sulfur (NaS) batteries with a specific energy greater than $100 \mathrm{~W}-\mathrm{hr} / \mathrm{K}_{3}$ to attain power levels in the 10's of kilowatts (kW) for space.

Major General Robert R. Rankine, Jr., Vice Commander, U.S. Air Force Space Division, stated early this year, "The United States is committed to an expanded role in space. Our national security would be at risk without our existing space assets. For this reason we cannot afford to shy away from an aggressive space program." (1). As our role in space expands, the number of spacecraft and the electric power levels of space platforms wili increase. Recent studies conductec by the Air Force Space Technology Center (AFSTC) indicate that, with or without a Space Defense Initiative (SDI), military space power requirements will grow by an order of magnitude in the next 20 years (2). Thus, photovoltaic power sources have not only played a major factor in primary space power over the past 25 years but are forseen to continue to do so into the twenty-first century.

Space Power Technology for the Iwenty-First Century (SPT 21), a planning activity co-sponsored by the AFSTC and the Air Force Wright Aeronalstical Laboratories (AFWAL), prepared a long-range technology plan for the development of space power technology options to meet future anticipated Air Force space system power needs (3). SPT 21 providea a roadmap for research and development efforts required to provide a strong technology base to support our nation's increasing dependence upon space assets for its national security. The top priority is 
focused on technologies that meet near-term moderate power and specific artificial threat requirements. Specifically, it stresses that technologies enabling lower weight, higher power, and threat-survivable solar photovoltaic subsystems should be the primary power technology development activity for next generation spacecraft. Historically, military spacecraft have been characterized by:

- low power requizements $(-1 \mathrm{~kW})$

- relatively short mission durations (4-7 yr)

- minimal requirements for artificial threats

- small block buys (less than five spacecraft)

- high cost per watt

Now the drivers in spacecraft are:

- increasing power demands (10.s of $\mathrm{kW}$ )

- extended mission lifetimes (10 yr)

- survivability to artificial threat environments

- larger constellations, e.g., GPS

- lower cost per watt

The present drivers for space power subsystems present both tremendous opportunities and problematic issues to the space photovoltaic community. Survivability to artificial environments will not be discussed further, since it is beyond the scope of this paper. Issues such as higher efficiency solar cells, large and rigid support structures, and stable, high-stzength, lightweight materials must be addressed if solar photovoltaic technology is to compete with nuclear and other alternative sources of primary power. Space power, subsystem cost and weight are especially major factors today for consideration in military spacecraft. Again quoting Gen. Rankine, "We cannot afford to continue the current trends in launch cost per pound on orbit." Innovative orbit transfer systems such as the orbital transfer and maneuvering vehicles with radiationtolerant, lightweight solar arrays specifically address this problem and could become essential to an enhanced presence in space (4). Avenues of opportunity for expanding solar photovoltaics in future military spacecraft are discussed below and will focus primarily on lowering launch costs by decreasing power subsystem weight and cost.

\section{PRESENT-DAY POWER SOURCES}

In the United States, the status of implemented and developing solar photovoltaic power sources and energy storage systems for military and civilian spacecraft can be described generically as follows:

- Si solar cells of 13 to $15 \%$ AMO space qualified

- Production quantities available up to $8 x$ $8 \mathrm{~cm}$ in area

- GaAs solar coll. at 16 to 187 amo efficiency in production

- Cell areas of $2 \times 4 \mathrm{~cm}$ GaAs fully qualified for space use
- $20 \%$ efficient, large area, and low weight GaAs under development for production scale-up (Air Force Manufacturing Technology Program)

- High power, lighter weight, and lower cost solar array structures being developed (advanced photevoltaic solar array program under NASA funding)

- Advanced high-efficiency multibandgap (MeG) solar cell developments are being funded by AFTAL

- NiCd batteries of $28 \mathrm{~W}-\mathrm{hr} / \mathrm{Kg}$ presently used in geosynchronous orbit

- $40 \mathrm{~W}-\mathrm{hr} / \mathrm{Kg} \mathrm{NiH}$ in production and greater than $100 \mathrm{~W}-\mathrm{hr} / \mathrm{Kg}$ NaS batteries in development

If solar photovoltaic/battery energy storage power subsystems are to compete with either nuclear or solar dynamic in future space sys:ems, a key factor is a decrease in total system launch weight. The incentive for decresed launch costs arises from the high cost of heavy launch vehicles needed to boost into orbit heavy payloads of either sophisticated, single large or multiple tandem smaller satellites. The electric power subsystem (EPS) weight is approximately $20 \%$ of the spacecraft dry weight, and the solar array is about $40 \%$ of the EPS weight.

Reducing solar array mass has been one cf the primary areas of focus for decreasing overall lift weight and lessening the launch vehicle cost. This is important for high earth altitude or geosynchronous orbit missions due to launch vehicle cost and a restricted launch vehicle capability to boost payload into high earth orbits. In addition, a reduction in solar array mass and/or an increase in specific power ( $w / \mathrm{kg}_{\mathrm{g}}$ ) enables a greater weight allocation for more sensors, transponders, or additional payload on the existing spacecraft bus. Furthermore, higher areal power densities. $\left(\mathrm{W} / \mathrm{m}^{2}\right)$ permit less

limited sensor view angles and decrease strenuous requirements on attitude and orbital control mechanisms.

Three Air Force spacecraft which occupy generic low-earth (LEO), mid-earth (MEO), and high-earth or geostationary orbits (GEO) are the Defense Meteorological Satellite Program (DMSP), the Global Positioning System (GPS), and the Defense Satellite Communication System (DSCS), respectively. Figure 1 illustrates the mass breakdown of the EPS for each of the three spacecraft. As shown and previously stated, the solar array represents approximately $40 \%$ of the power subsystem weight, with the battery energy storage contributing the other major weight factor in the EPS. It will be shown how the utilization of advanced power source technology and spectfically advanced solar photovoltales will substantially reduce the total launch weight resulting from reducing the EPS weight. 


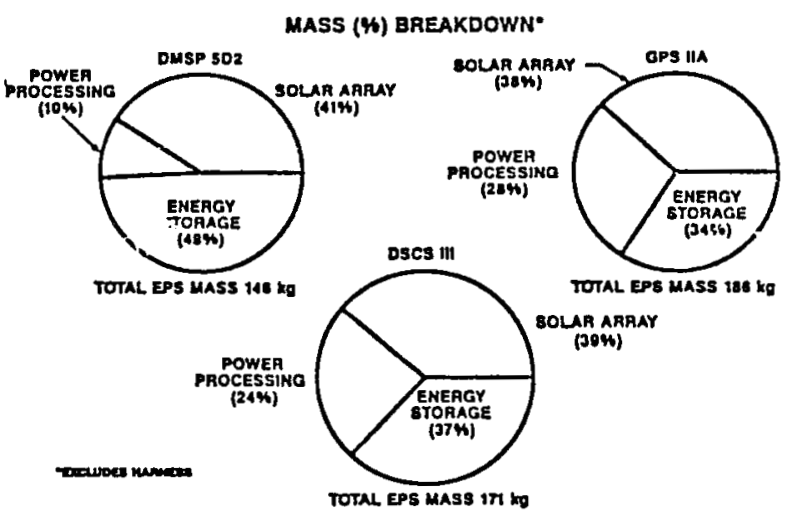

Figure 1. Military Spacecraft EPS

A comparison of potential mass benefits can be made to the present spacecraft in Figure 1 , if planned upgrades use advanced solar array and battery energy storage technology (5). This is illustrated in Table 1 for flexible substrate arrays replacing state-of-the-art rigid arrays, GaAs solar cells replacing $\mathrm{Si}$, and $\mathrm{NiH}_{2}$ and $\mathrm{NaS}$ batteries replacing NiCd technology. These weight enhancements can be achieved with either available technology or technology under development. All of the advanced power source areas mentioned above must continue to be funded, supported, and implemented if cost and weight advantages are to be realized on the next block design spacecraft. Potential impact on total launch and spacecraft replacement savings is illustrated in Table 2, along with the projected increase in advanced EPS technology hardware cost. The last column in Table 2 describes the average annual cost of placing an operating satellite on orbit. The increased cost of advanced technology hardware to extend mission life of an existing satellite is far less than the cost to replace it on orbit. Thus, significant launch savings can be realized when lightweight flexible solar arrays are used in conjunction with thin, high-efficiency solar cells and high-energy density batteries.

If the ratio of increased cost of implementing advanced technology with respect to total mass savings is calculated, the specific cost in 1988 dollars per pound saved is shown in the middle column of Table 3 . The last column of Table 3 gives the spacecraft specific cost with respect to state-of-the-art EPS technology. Clearly, the addtional hardware specific cost for advanced technology is approximately a factor of ten less than present overall spacecraft specific cost. It is also seen that the $\Delta$ hardware specific cost goes down by a factor of 2 to 3 when flexible substrate $\mathrm{Si}$ solar arrays and $\mathrm{Ni}_{2}$ batteries are substituted with flexible substrate GaAs solat arrays and NaS batteries. The MBG solar cell does not follow the cost-effective trend for implementing advanced technology in this table, primarily because the MBG cells are projected to have a relatively higher initial cost associated with multistep cell processing and lower yield compared to advanced SJ solar cells.

Table 1. Advanced Technology Impacts

\begin{tabular}{|c|c|c|c|}
\hline $\begin{array}{c}\text { Power } \\
\text { Technologies }\end{array}$ & $\begin{array}{c}\text { Total } \\
\text { Mass } \\
\text { Savings } \\
\text { (1b) }\end{array}$ & $\begin{array}{c}\text { Mass } \\
\text { Savings } \\
z \text { of EPS }\end{array}$ & $\begin{array}{l}\text { Mass } \\
\text { Savings } \\
\text { \% of } \\
\text { spacecraft } \\
\text { (Dry) }\end{array}$ \\
\hline GPS IIA & & & \\
\hline $\begin{array}{l}\text { FLEX } \mathrm{Si}-\mathrm{NiH}_{2} \\
\text { FLEX } \mathrm{GaAs}-\mathrm{NiH}_{2} \\
\text { FLEX GaAs }-\mathrm{NaS}^{2} \\
\text { MBG - NaS }\end{array}$ & $\begin{array}{l}148 \\
147 \\
188 \\
173\end{array}$ & $\begin{array}{l}36.1 \\
35.9 \\
45.9 \\
42.2\end{array}$ & $\begin{array}{r}8.7 \\
8.6 \\
11.0 \\
10.2\end{array}$ \\
\hline DMSP 5D2 & & & \\
\hline $\begin{array}{l}\text { FLEX } \mathrm{Si}-\mathrm{NiH}_{2} \\
\text { FLEX GaAs }-\mathrm{NiH}_{2} \\
\text { FLEX } \mathrm{GaAS}-\mathrm{NaS} \\
\text { MBC - NaS }\end{array}$ & $\begin{array}{l}123 \\
122 \\
176 \\
166\end{array}$ & $\begin{array}{l}38.1 \\
37.7 \\
54.5 \\
51.4\end{array}$ & $\begin{array}{l}6.8 \\
6.7 \\
9.7 \\
9.2\end{array}$ \\
\hline DSCS III & & & \\
\hline $\begin{array}{l}\text { FLEX Si - } \mathrm{NiH}_{2} \\
\text { FLEX GaAs - } \mathrm{NiH}_{2} \\
\text { FLEX GaAs - NaS } \\
\text { MBG - NaS }\end{array}$ & $\begin{array}{r}87 \\
86 \\
167 \\
161\end{array}$ & $\begin{array}{l}23.2 \\
22.9 \\
44.4 \\
42.8\end{array}$ & $\begin{array}{l}4.5 \\
4.4 \\
8.6 \\
8.3\end{array}$ \\
\hline
\end{tabular}

Table 2. Advanced Technology Impacts

\begin{tabular}{|c|c|c|c|c|}
\hline \multirow[b]{2}{*}{$\begin{array}{l}\text { Power } \\
\text { Iechnologites }\end{array}$} & \multirow{2}{*}{$\begin{array}{l}\text { Total } \\
\text { Mass } \\
\text { Savings } \\
\text { (1b) }\end{array}$} & \multirow{2}{*}{$\begin{array}{l}\text { Increased } \\
\text { Harduare } \\
\text { Cost } \\
(\$ 00)\end{array}$} & \multicolumn{2}{|c|}{ Opportunfty Savings* } \\
\hline & & & $\begin{array}{l}\text { Launch* } \\
(\$ 00)\end{array}$ & $\begin{array}{c}\text { Replacement** } \\
(\$ 00)\end{array}$ \\
\hline \multicolumn{5}{|l|}{ GPS IIA } \\
\hline $\begin{array}{l}\text { FLEX } \mathrm{Si}-\mathrm{NiH}_{2} \\
\text { FLEX GaAs }-\mathrm{NiH}_{2} \\
\text { FLEX GaAs - } \mathrm{NaS} \\
\text { MBG - NaS }\end{array}$ & $\begin{array}{l}148 \\
147 \\
188 \\
173\end{array}$ & $\begin{array}{r}\$ 430,300 \\
304,900 \\
272,900 \\
844,800\end{array}$ & $\begin{array}{r}\$ 3,600,000 \\
3,550,000 \\
4,600,000 \\
4,200,000\end{array}$ & $\$ 6,000,000$ \\
\hline \multicolumn{5}{|l|}{ DMSP SD2 } \\
\hline $\begin{array}{l}\text { FLEX Si }-\mathrm{NiH}_{2} \\
\text { FLEX GaAs }-\mathrm{NiH}_{2} \\
\text { FLEX GaAs }-\mathrm{NaS}^{2} \\
\mathrm{MBC}-\mathrm{NaS}\end{array}$ & $\begin{array}{l}123 \\
122 \\
176 \\
166\end{array}$ & $\begin{array}{r}\$ 413,300 \\
236,100 \\
204,100 \\
761,900\end{array}$ & $\begin{array}{r}890,000 \\
880,000 \\
1,300,000 \\
1,200,000\end{array}$ & $\$ 23,000,000$ \\
\hline \multicolumn{5}{|l|}{ DSCS 11I } \\
\hline $\begin{array}{l}\text { FLEX Si }-\mathrm{NiH}_{2} \\
\text { FLEX GaAs }-\mathrm{NiH}_{2} \\
\text { FLEX GaAs }-\mathrm{NaS} \\
\text { MBG - NaS }\end{array}$ & $\begin{array}{r}87 \\
86 \\
167 \\
161\end{array}$ & $\begin{array}{r}\$ 506,400 \\
341,800 \\
293,800 \\
937,800\end{array}$ & $\begin{array}{r}\$ 3,200,000 \\
3,100,000 \\
6,200,000 \\
6,000,000\end{array}$ & $\$ 8,400,000$ \\
\hline $\begin{array}{l}\text { Saving: } \\
\text { nent Sav }\end{array}$ & . & $\begin{array}{l}\text { ch co } \\
\text { ngs o } \\
\text { age ce } \\
\text { gn } 11\end{array}$ & $\begin{array}{l}\$ / 1 b) \text { cimes } \\
\text { of epacecta }\end{array}$ & $\begin{array}{l}\text { cotal mass } \\
\text { t divided by }\end{array}$ \\
\hline
\end{tabular}


Table 3. Advanced Technology - Cost Effectiveness

\begin{tabular}{|c|c|c|c|}
\hline $\begin{array}{c}\text { Power } \\
\text { Technologies }\end{array}$ & $\begin{array}{l}\text { Total } \\
\text { Mass } \\
\text { Savings } \\
\text { (1b) }\end{array}$ & $\begin{array}{c}\Delta \text { Hardware } \\
\text { Specific } \\
\text { Cost } \\
(\$ 00 / 1 b)\end{array} \mid$ & $\begin{array}{c}\text { Spacecraft } \\
\text { Specific } \\
\text { Cost } \\
(\$ 00 / 1 b)\end{array}$ \\
\hline $\begin{array}{l}\text { FLEX } \mathrm{Si}-\mathrm{NiH}_{2} \\
\text { FLEX GaAs - } \mathrm{NiH}_{2} \\
\text { FLEX GaAs - NaS } \\
\text { MBG - NaS }\end{array}$ & $\begin{array}{l}148 \\
147 \\
188 \\
173\end{array}$ & $\begin{array}{l}2900 \\
2100 \\
1500 \\
4900\end{array}$ & 26,000 \\
\hline $\begin{array}{l}\text { FLEX } \mathrm{Si}-\mathrm{NiH}_{2} \\
\text { FLEX GaAs }-\mathrm{NiH}_{2} \\
\text { FLEX GaAs - NaS } \\
\text { MBG - NaS }\end{array}$ & $\begin{array}{l}123 \\
122 \\
176 \\
166\end{array}$ & $\begin{array}{l}3400 \\
2000 \\
1200 \\
4600\end{array}$ & 28,000 \\
\hline $\begin{array}{l}\text { FLEX } \mathrm{Si}-\mathrm{NiH}_{2} \\
\text { FLEX GaAs }-\mathrm{NiH}_{2} \\
\text { FLEX GaAs - } \mathrm{NaS} \\
\text { MBG - NaS }\end{array}$ & $\begin{array}{r}87 \\
86 \\
167 \\
161\end{array}$ & $\begin{array}{l}5900 \\
4000 \\
1800 \\
6000\end{array}$ & 43,000 \\
\hline
\end{tabular}

OPPORTUNITIES FOR AIR FORCE SPACE SOLAR PHOTOVOLTAICS

As previously stated, the Air Force's capability in space communications, surveillance, weather, and navigation will continue to increase into the next century. The number of spacecraft and their respective power requirements are projected to multiply by a factor of 5 to 10 over present mission schedules. This overall growth will increase efficiency requirements on electric power and spacecraft subsystems to accomodate enhanced payloads and will drive the spacecraft power subsystem to decrease its overall mass and cost. The potential for advanced power source technology and its mass and cost impacts have al ready been shown. If follow-on block spacecraft continue to use solar arrays, the type of advanced photovoltaic solar cell devices to benefit next generation spacecraft design must be considered. To do this, we can examine present-day Air Force geosynchronous Si solar array technology (6). The constituent panel and full-size array (including boom assemblies and fittings) power parameter features are shown in Table 4.

Panel structures are composed of a cell stack mounted on a substrate. The cell stack is made up of approximately $0.015-\mathrm{cm}$ thick fused-silica or ceria-stabilized microsheet coverglass adhered to a $0.020-\mathrm{cm}$ thick $\mathrm{Si}$ solar cell which is $2 \mathrm{x}$ $4 \mathrm{~cm}$ to $6 \times 6 \mathrm{~cm}$ in area. The panel substrate is typically aluminum honeycomb core with aluminum facesheets. Adhesive bonds, dielectric coatings, and thermal control paints are included in the panel and array structure. The solar cells have a 13 to $14 \pi$ conversion efficiency at AMO, producing power levels at beginning of life (BOL) of 1 to $2 \mathrm{~kW}$. A typical solar panel configuration is shown in Figure 2.
Table 4. Present Day GEO Silicon Solar Cells with Rigid Array Technology

\begin{tabular}{|c|c|c|}
\hline & Panel & Array \\
\hline $\begin{array}{l}\text { Specific power } \\
(\mathrm{W} / \mathrm{kg})\end{array}$ & $23.8-36.3$ & $21.0-28.2$ \\
\hline $\begin{array}{l}\text { Areal power } \\
\text { density }\left(\mathrm{W} / \mathrm{m}^{2}\right)\end{array}$ & $111.5-113.8$ & $111.5-113.8$ \\
\hline $\begin{array}{l}\text { Areal density } \\
\left(\mathrm{kg} / \mathrm{m}^{2}\right)\end{array}$ & $3.14-4.67$ & $4.04-5.32$ \\
\hline
\end{tabular}

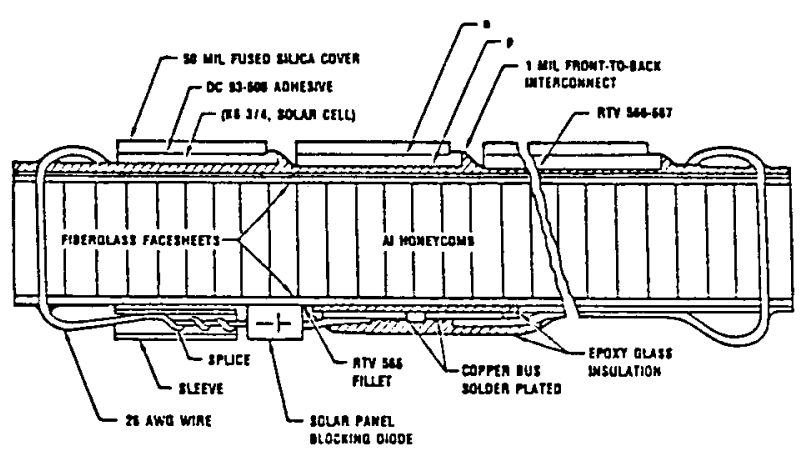

Figure 2. Conventional Solar Cell Interconnect

Two key drivers for advanced solar photovoltaics are a decrease in overall array subsystem weight at some level of power, i.e., an increase in specific power ( $/ \mathrm{kg})$; or an increase in conversion efficiency or output power at a constant array area, i.e., an increase in areal power density $\left(\mathrm{w} / \mathrm{m}^{2}\right)$. Decreased photovoltaic EPS weight to decrease launch cost is being demonstrated in the Advanced Photovoltaic Solar Array (APSA) program (7) under sponsorship from the NASA Office of Aeronautics and Space Technology (OAST). This program is pursuing array design technology with a specific power goal of $300 \mathrm{~W} / \mathrm{kg}$ at the $25 \mathrm{~kW}$ power level at BOL. Under the management of the Jet Propulsion Laboratory (JPL), an intermediate near-term specific power goal of $130 \mathrm{~W} / \mathrm{kg}$ at a $10 \mathrm{~kW}$ (BOL) array power level has been seiected. The design is a lightweight, flexible-blanket flatpack, foldout solar array based on existing and nearterm photovoltaic components and structural members. This design is being seriously considered for advanced military spacecraft, since it would provide a cost- and launch weighteffective alternative to present rigid-panel planar solar arrays. Flexible substrate solar arrays can provide greater than a fourfold improvement in the specific power of rigid arrays (e.8.. see Table 4). Indeed, the des $1 \mathrm{gn}$ of large $(5-50 \mathrm{~kW})$, lightweight solar array structures is an opportunity for the photovoltaic industry. 


\section{ORKENAL PAGE IS OF POOR QUALITY}

However, the assembly, hand 1 ing, integration, test, dynamics, and control are all issues that will challenge the photovoltaic systems engineer and the system's competitiveness with alternative power subsystems such as solar dynamic and nuclear.

A major problem for low-altitude earth o:bit missions is not so much the solar array mass factor but the environmental drag on the surface of the array, causing attitude adjustrents with an auxiliary reaction control gas thruster subsystem and decreasing the fuel supply and mission life. Increasing the absolute efficiency of the constituent solar cells not only increases the areal power density $\left(\mathrm{W} / \mathrm{m}^{2}\right)$ but also the specific power. Furthermore, not only does increasing cell efficiency have a direct payoff in decreased array area at the same power level, but smaller arrays will interfere less with desired antenna and sensor locations on spacecraft with field-of-view limitations. If one takes the present technology for GEO Si solar arrays as illustrated in Table 4 and substitutes present-day production GaAs solar cells with $17 \%$ conversion efficiency, not only is there an increase in areal power density but also an increase in specific power ( 8 ). This is shown in the second column of Table 5. Implementing the rechnology goals of the Air Force Manufacturing Technology Program for lightweight, higher efficiency GaAs/Ge solar cells will enhance the performance even more, as illustrated in the third column of that table.

Table 5. Comparative Performance for Advanced Solar Cells with Rigid Array Technology

\begin{tabular}{|c|c|c|c|}
\hline & $\begin{array}{l}\text { Si } \\
\text { Array }\end{array}$ & $\begin{array}{c}\text { GaAs/GaAs } \\
\text { Array }\end{array}$ & $\begin{array}{c}\text { GaAs } / \mathrm{Ge} \\
\text { Array }\end{array}$ \\
\hline $\begin{array}{l}\text { Efficiency } \\
(\xi, A M O)\end{array}$ & 13 & 17 & 19 \\
\hline $\begin{array}{l}\text { Specific power } \\
(\mathrm{W} / \mathrm{kg})\end{array}$ & 33.2 & 34.1 & 44.0 \\
\hline $\begin{array}{l}\text { Areal power density } \\
\left(W / m^{2}\right)\end{array}$ & 103.3 & 122.7 & 137.8 \\
\hline Cell thickness (mm) & 0.20 & 0.25 & 0.125 \\
\hline
\end{tabular}

The APSA goal of $130 \mathrm{~W} / \mathrm{kg}$ (BOL) utilizes $13.5 \% \mathrm{Si}$ cells which are $0.055 \mathrm{~mm}(0.0022 \mathrm{in.})$ thick. If $0.075 \mathrm{~mm}(0.003 \mathrm{in.})$-thick GaAs $/ \mathrm{Ge}$ solar cells of $20 \%$ AMO conversion efficiency were to be substicuted for the Si celis, the panel specific power and areal power density would be $346 \mathrm{~W} / \mathrm{kg}$ and $243 \mathrm{~W} / \mathrm{m}^{2}$, respectively (9). This rechnology would more than meet the NASA goal and would be more than a factor of 10 improvement in specific power over the present Air Torce rigid solar array design for GEO orbits.
ADDITIONAL CONSIDERATIONS FOR AIR FORCE SPACE PHOTOVOLTAICS

For Air Force and military missions, the plan and focus from SPT-21 for solar photovoltaic power systems is on technology needs and options For demonstrating higher efficiency solar cells .nd lighter weight array structures for mission needs in the early 1990's. Solar array structures ran be either planar or concentrative in cptical design. Major considerations tor both planar and concentrative photovoltaic arrays are their strength and dynamic control, reliable deployment and retraction mechanisms, and lightweight and rigid structural design. As previously stated, the near-term, higher-efficiency, radiationtolerant solar cell options are thin $(0.003$ in.) $\mathrm{Si}$ and GaAs, with AMO conversion efficiencies ranging from 14 to $15 \%$ for $\mathrm{Si}$, and 16 to $18 \%$ for GaAs cells. A greater decrease in launch costs and increase in payload capability will come when advanced MBG solar cells are developed with 20 to $30 \%$ efficiency.

To maintain compatibility with existing power conditioning designs on spacecraft, two terminal (2T) devices are preferred. Since the power subsystem engineer treats the solar cell as one of the many "components" for integration into the solar panel, the preference is typically a requirement decreed by the array contractor. All solar cells used on military spacecraft to date have incorporated module configurations with $2 T$ devices, and the historical data base is on $2 \mathrm{~T}$ solar cells and their integration with $2 T$ power conditioning units. Options and opportunities for MBG solar cells would increase dramatically if module configurations utilizing three or four terminal devices were to be incorporated with power conditioning and solar array harnessing designed specifically for these multi-terminal devices. Instiead of power conditioning units designed on current matched constituent cells in series in a MBG cell stack, voltage matching with subcells wired in parallel would be used (10). Advantages of this design include a wider selection of band gaps for optimal performance, less costly device processing, and better matched performance characteristics with radiation degradation. Alternative module configurations are an issue that needs to be addressed by the array and spacecraft manufacturers and supported by customers if high-efficiency three- and four-terminal MBG solar cells presently being developed by the photovoltaic community are to be utilized in space.

The only way to approach NASA's goal of $300 \mathrm{~W} / \mathrm{kg}$ for solar arrays and increase the specific power density of the overall electrical power subsystem for power levels up to and greater than $50 \mathrm{~kW}$ is to achieve cell efficiencies greater than $20 \%$ and energy storage with a weight energy density greater than $50 \mathrm{~W}-\mathrm{hr} / \mathrm{kg}$. The improvements in cell efficiency and solar panel weight will be realized only through the use of thin, high efficiency MBG solar cells on flexible, lightweight planar and concentrative 
solar arrays. MBG devices, now being developed in laboratory-funded programs and progressing towards space-qualified demonstration, have a potential for use, if system-level designers consider the integration of three- or fourterminal devices in full-scale arrays.

\section{ADVANCED TECHNOLOGY IMPACTS ON} FUTURE AIR FORCE MISSIONS

To emphasize once more, advanced solar photovoltaic technology will be utilized in future, high-power spacecraft only if it can compete in both weight and cost-effectiveness with alternative technologies. Figures 3 through $5 \mathrm{give}$ the solar panel area for a required EOL power after 10 years in geosynchronous orbit for various solar cell technologies. The BOL areal power densities range from 114 to $288 \mathrm{~W} / \mathrm{m}^{2}$. For a $5-\mathrm{kW}$ EOL power requirement in GEO after 10 years, Figure 6 shows the spacecraft electrical power subsystem specific power for various solar photovoltaic and energy storage power subsystem technologies (11). Solar photovoltaic-based power subsystems become even more weight-effective than competing technologies when solar cell efficiencies greater than $20 \%$ and 1 ightweight, Elexible array structures are utilized. With MBG solar cell efficiencies in the 25 to $30 \%$ range and flexible, lightweight arrays, solar photovoltaics for spacecraft EPS can be weight-competetive up into the $50 \mathrm{~kW}$ power level region (2).

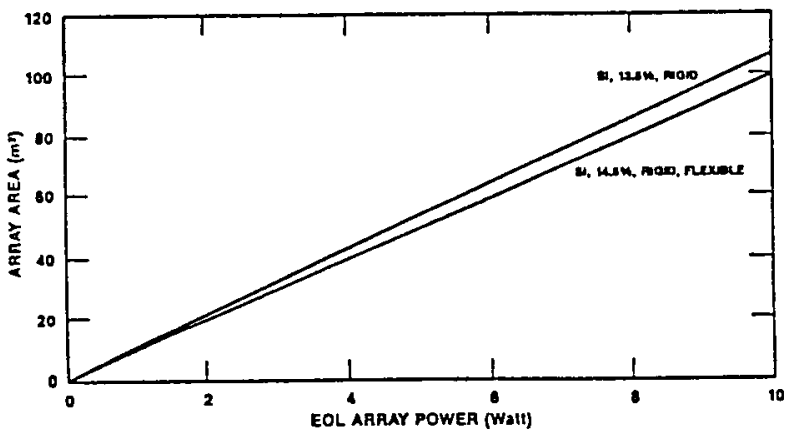

Figure 3. Solar Array Area versus EOL Power

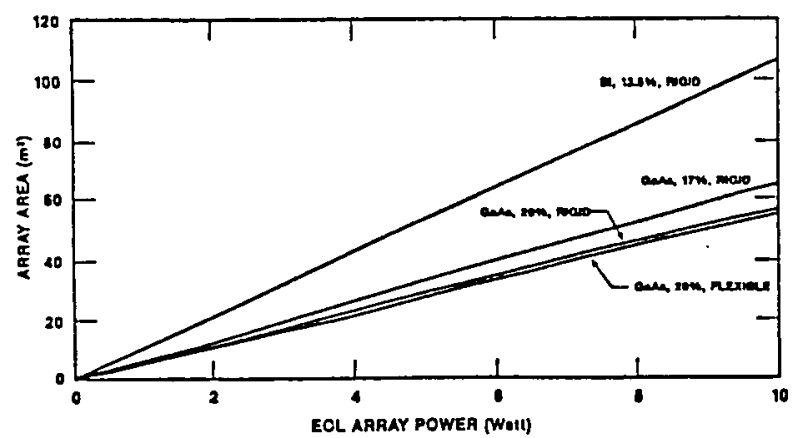

Figure 4. Solar Array Area versus EOL Power

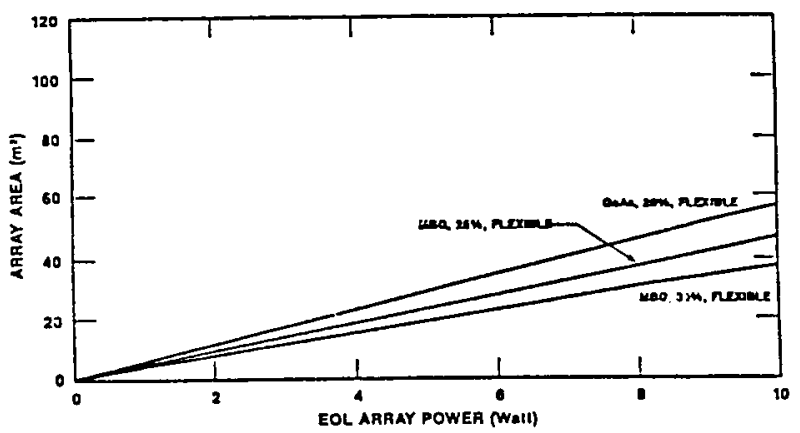

Figure 5. Solar Array Area vezsus EOL Power

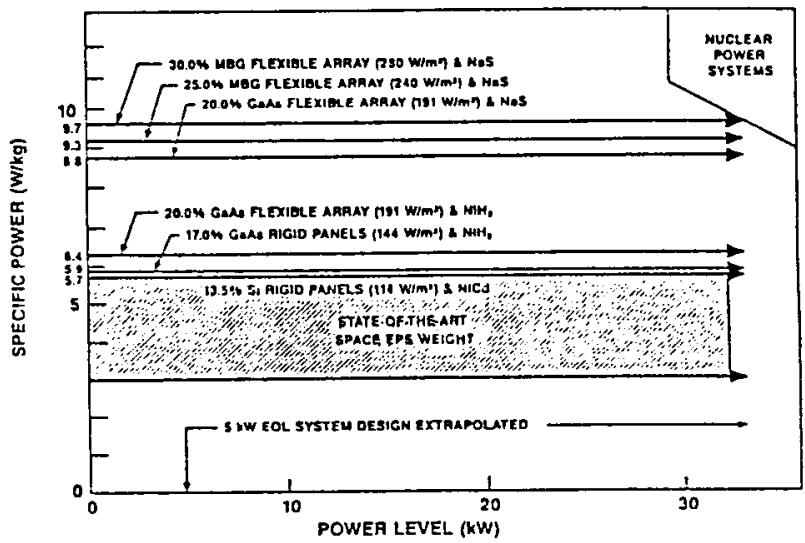

Figure 6. Power System Characteristics

As a final comparison of the specific power advantages of different solar cell and array technologies, Figure 7 plots array weight versus EOL power for a 10-year GEO mission. Specific array power varies from $50 \mathrm{~W} / \mathrm{Kg}$ for a $13.5 \% \mathrm{Si}$ rigid panel to $215 \mathrm{~W} / \mathrm{Kg}_{\mathrm{S}}$ for $20.0 \%$ GaAs on flexible, lightweight panels. Thus, Air Force research funds and planning activities include the development of higher efficiency single and MBG solar cells, lightweight solar array structures, and high-energy density rechargeable batteries as the approach to attaining higherthan-present power levels in space.

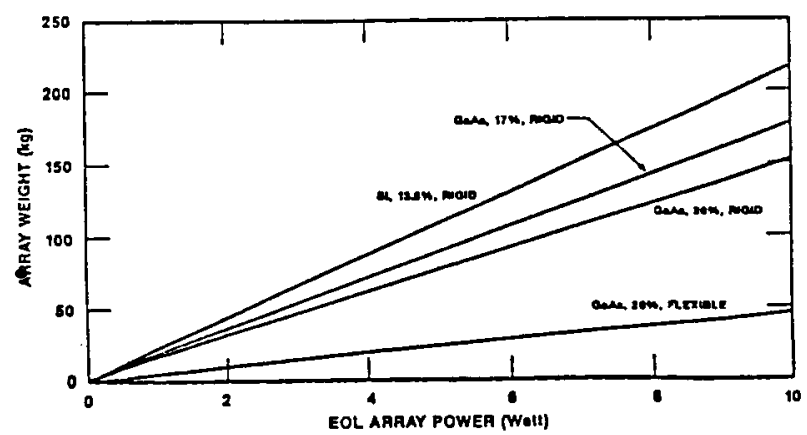

Figure 7. Solar Array Weigit versus EOL Power 


\section{ORIGINAL PAGE IS \\ OF POOR QUALITY}

Increasing solar-panel specific power and areal power density with lighter weight array substrate structures and advanced high-efficiency solar cells can favor solar photovoltaics at power levels over an order of magnitude higher than in present block spacecraft. This will prove to be so only if, however, the cost of implementing advanced power source hardware is less than the savings gained from reduced launch sys tem weight.

\section{SUMMARY - AIR FORCE ISSUES AND OPPORTUNITIES}

Space solar-photovoltaic-based electrical power subsystems have a major potential opportunity for decreasing overall spacecraft mass and launch cost and also providing more power for increased payload. Structural. dynamic, and mechanical engineers will play a more important and active role along with the photovoltaic specialist in developing large, lightweight, strong, and rigid support structures on which will be mounted high-efficiency solar cells and modules. Through implementation of such technology, space solar arrays can be launched with 200 to $250 \mathrm{~W} / \mathrm{m}^{2}$ areal power density and 100 to $200 \mathrm{~W} / \mathrm{kg}$ specific power in the not too distant future. Power levels could approach $50 \mathrm{~kW}$ for the electrical orbital transfer and maneuvering vehicles and beyond for solar energy collecting platforms in space.

Although solar photovoltaics meet present and near-term power system technology needs, higher power levels cause concern for system feasibility unless lightweight, flexible solar arrays and high efficiency solar cells are considered and utilized. Power processing and electrical conditioning subsystems must be developed to handle the possible wide range of high-efficiency MBG solar cells that are being investigated with two, three, or four terminal structures and being integrated into various module configurations.

Solar photovoltaics is still cost effective when compared to alternative power technologies, and it will remain competitive providing both advanced lightweight support structures and high-efficiency solar cells can be produced with high yield and high throughput process technology.

\section{NASA SPACE MISSION ISSUES AND OPPORTUNITIES}

While there is a great deal of similarity between military and civilian photovoltaic space power system technology drivers, with the result that many of the issues and opportunities are the same in both mission realms, the requirement to withstand various kinds of artificial threats is uniquely military. Such a requirement can have a wide ranging impact on the nature of the technology employed in a space photovoltaic system, but the net effect is of ten that military systems will be heavier than nonmilitary systems of comparable power and effictency. Although most NASA missions usually place a premium on minimizing system mass, particularly in the early stages of an : ovanced development program, other consideratiuis cari often have a significant impact on the technology that is finally selected for flight.
An example of the preceding will be investigated later in this discussion. When minimum mass considerations are dominant, however, the discriminator used is power per unit mass, or specific power $(\mathrm{W} / \mathrm{kg})$, whether at the component, subsystem or system level. Generally, only those technologies that can have a major impact at the system level will be developed.

Recently there has been a renewed interest within NASA to extend our physical presence in space, either by a manned visit to Mars, or a return to the moon, or both. Initial activities on either surface would be followed by the establishment of some kind of habitable outpost, which could evolve over time into a permanent manned base of significant size and capability. A new aspect of the attempt to establish this sort of permanent presence is that the mission requirements are no longer fixed, but will evolve over time. Just as the base is expected to evolve in size, complexity, and capability from its initial outpost configuration, the power system will also evolve from an initial few kilowatts to the megawatt range. It now becomes necessary to examine and develop a time dependent set of requirements for the power system, and to put in place a set of advanced R\&D programs that are properly phased to produce the needed technology at the right time. In addition to the above manned-mission classes, there is also a growing interest in expanding the scope and intensity of those space activities that can help us develop a better understanding of our own planet and mankind's effect on the global processes that keep it a habitable place to live. The of fice of Aeronautics and Space Technology (OAST) within NASA has taken the first steps in both directions with the implementation of its Civilian Space Technology Initiative (CSTI) and Project Pathfinder. CSII contains the High Capacity Power program, and Pathfinder contains both a Surface Power and a Rover Power program. A.11 three programs are intended to produce a set of technology options for future mission planners that will significantly enhance our capability to accomplish a variety of ambitious space goals, from vigorous manned exploration to intensified science activities.

\section{High Capacity Power Applications}

The High Capacity Power program addresses the development of power system technology for missions requiring $100 \mathrm{~kW}$ or more. It is at present focused exclusively on thermal-to-electric power conversion from either a solar thermal source or a nuclear source. The nonsolar baseline technology is the $S P-100$ nuclear reactor, which will incorporate thermoelectric conversion at a net efficiency in the range of 3 to $4 \%$. The solar thermal conversion system will use heat engine technology, either a free piston stirling engine or an advanced brayton cycle engine. In its advanced version, the $S P-100$ reactor would use a free piston atirling engine, which would increase that system's efficiency to the mid-20\% range. It is generally held that photovoltaic power systems will not be competitive on a mass basis with the nuclear/stirling engine system at the higier power levels under consideration, particulerly when there is a large energy storage 
requirement (e.g., a lunar base), or when there is a high potential for space radiation damage, such as for long-duration missions in or through the Van Allen belts. That contention will be addressed in the paragraphs that follow.

The issues associated with long-duration storage times will be discussed in the section that deals with the new initiative in Surface Power Systems. In the case of orbit transfer missions requiring passage chrough tne $\mathrm{V}$ a.d Allen belts, photovoltaic power systems must be capable of specific powers approaching or exceeding $100 \mathrm{~W} / \mathrm{kg}$ at end of life to be competitive with the conceptual designs for the thermal-toelectric conversion systems mentioned above. While progress has been made in the development of thin silicon solar cells and lightweight structures, it is still beyond the reach of silicon cell technology to assure long-term operation in the Van Allen belts. Typical projections from such mission profiles indicate that during the first trip, a solar array could be exposed to $1 \mathrm{MeV}$ electron equivalent fluences approaching $10^{17} / \mathrm{cm}^{2}$, which would reduce the output of a standard silicon solaz array, such as intended for the space station, to less than 10\% of its BOL power. There is at present no lightweight silicon solar cell, ever with a minimal protective coverglass, which can be incorporated on the most advanced lightweight array structure(s) under development [APSA, e.g., (12)] that can meet the above requirement. Acceleration levels associated with electric propulsion booster rockets, although not large, (typicaliy hundreds of $\mathrm{g}^{\prime} \mathrm{s}$ ), still impose a minimum set of requirements on the array structural mass, which will in turn restrict the mass that can be used for physical shielding of the solar cells. It is clear that a new generation of solar cells is needed that are essentially immune to radiation damage, either through some sort of inherent resistance to the effects of space radiation, or through some sort of easily implemented damage removal mechanism. Leading candidates in that regard are InP homojunction cells, particularly in conjunction with concentrated sunlight levels near loox, and thin film cells such as amorphous silicon and CuInSe $2(13,14,15)$.
Almost all of the information that now exists on the suitability of the above cell types for space applications of any sort, let alone in the high radiation damage orbits, is preliminary in nature. [The first spaceflight data on InP cells, for example are being reported at this conference (16).] Table 6 provides a comparison of space solar cell performance as determined in laboratory devices for several cell types. A great deal o work yet remains to develop fully space-qualiied designs of any of them. The payoff for future mission planners is significant, since such capability provides them with an important additional option to consider as they formulate mission objectives and requirements. The payoff for photovoltaic power system applications is enormous, however, since the technology would open up a whole new set of mission opportunities from which photovoltaic power systems had otherwise been eliminated.

\section{SURFACE AND ROVER POWER SYSTEMS}

While the definition of a complete set of time-dependent requirements is an unfinished task, an understanding of key issues has been ceveloped to help guide focused technology ef torts within the Agency. The present discussion will be limited to the case for establishing an e :olutionary lunar base, since the same general considerations will apply, but with different associated numbers, to the case for Mars. Techrologies intended for a lunar base application will be driven by mass considerations, primarily because of the high cost of payload delivery to the lunar surface. Even if the assumption is made that low operational cost cargo vehicles will be available for transit from low earth orbit (e.g.. from the space station), to the moon, there will still be a high cost for delivery to LEO which must be considered. For comparison purposes the cost can be represented by a payload mass muleiplication factor which takes into account the total launch mass required to deliver the intended lunar base elements to LEO. Although a universally agreed-on value for such a multiplier does not exist, primarily because the exact nature of future heavy lift

Table 6. Photovoltaic Power Systems PV Cell Technology Sumary

\begin{tabular}{clcc}
\hline & \multicolumn{2}{c}{ Goal } \\
$\begin{array}{c}\text { Nfficiency } \\
(\%)\end{array}$ & $\begin{array}{c}\text { Rad. Deg. } \\
(\%)\end{array}$ & $\begin{array}{c}\text { Efficiency } \\
(\%)\end{array}$ & $\begin{array}{c}\text { Rad. Deg. } \\
(\%) a\end{array}$ \\
\hline 21 & 10 to 15 & 25.5 & 10 \\
In development & In development & 30 & 10 \\
19 & In development & 20 & 0 \\
6 & 10 & 10 & 5
\end{tabular}

$a_{\text {After }} 10$ years in GEO 


\section{ORIGINAL FAGE IS \\ OF POOR QUALITY}

launch capabilities is not known, a value of 5 has been assumed for this discussion, along with an assumed heavy lift vehicle capability of $91,000 \mathrm{~kg}(200,000 \mathrm{lb})$ to LEO. No further justification will be given for using them, except to mention that they have been used in advanced technology planning exercises within NASA, and that doing so allows a quantitative comparison of power system alternatives in terms of their "operational" impact, i.e., the number of launch vehicles required to deliver the system elements to LEO for subsequent transport to the lunar surface.

The key figure of merit for a photovoltaic array is the power per unit mass in watts per kilogram, W/kg. For a storage system the appropriate figure of merit is the amount of available energy per unit mass in watt-hours per kilogram, or $\mathrm{W}-\mathrm{hr} / \mathrm{kg}$. The advanced power system uses an ultralightweight photovoltaic array and an advanced hydrogen-oxygen regenerative fuel cell (RFC) for storage. The figures of merit for both systems are listed in Table 7 . Table 8

Table 7. Figure-of-Merit Comparisons for Photovoltaic/Electrochemical Technology Options

\begin{tabular}{|c|c|c|}
\hline & State of the Art & Advanced \\
\hline Array & $66 \mathrm{~W} / \mathrm{kg}$, OAST-1 & $\begin{array}{l}300 \mathrm{~W} / \mathrm{kg}, \mathrm{ultra}- \\
\text { lightweight }\end{array}$ \\
\hline Storage & $\begin{array}{l}14 \mathrm{w}-\mathrm{hr} / \mathrm{kg}, \\
\mathrm{NiH} \text { battery }\end{array}$ & $\begin{array}{l}1000 \mathrm{~W}-\mathrm{hr} / \mathrm{kg}, \\
\mathrm{H}-0 \mathrm{RFC}\end{array}$ \\
\hline
\end{tabular}

nuclear power system currently under development, and intended to have a specific power of $33 \mathrm{~W} / \mathrm{kg}$. The table provides compeliling evidence that there is a substantial payof $f$ to be had in developing the advanced PV/RFC techrology, particularly when placed in the "operational" context of the weight saved at LEO. A third case also exists, that in which the astronauts' stay would be 1 imited to the 336-hr lunar day with a night duty cycle of zero, or close enough to zero so that lander energy storage would be sufficient. In this scenario, only a photovoltaic array would have to be delivered to the Iunar surface. A state-ofthe-art PV array to supply $100 \mathrm{kWe}$ has a mass of $1515 \mathrm{~kg}$, while an advanced array would weigh only $333 \mathrm{~kg}$, a significant savings under a restricted mass budget.

Figure 8 provides a more graphic comparison between the mass of SOA photovoltaic/battery system, the advanced photovoltaic/regenerative fuel cell systems, and the SP-100 nuclear power system. As can be clearly seen, the advanced PV/RFC technology has the potential to reduce the mass of a 100 kWe lunar surface power system using state-of-the-art technology by more than a factor of 45 , to a value less than $2.5 \%$ of the mass of the latter. (The SP-100 system, even though projected to be lighter than the advanced PV/RFC system by a factor of 10 , will only save a little more than another $2 \%$ of the SOA system mass.) The long lunar night is clearly the major issue in determining the mass of the lunar base photovoltaic-electrochemical storage system. The key feature that allows such a large mass reduction is that the stored energy in an advanced regenerative fuel cell system is in the form of gaseous reactants stored in high pressure tanks, with the result that the RFC can approach 1000 $W-h r / k g$, a factor of 4 or 5 better than that projected for advanced batteries, and a factor of more than 60 better than SOA batteries (NiH, for example.)

Table 8. Comparison of Current and Advanced Photovoltaic Power Systems for Manned Lunar Base (Instrument Shielding Only for $S P-100.1$ )

\begin{tabular}{lllllll}
\hline $\begin{array}{l}\text { Power } \\
\text { Level } \\
(\mathrm{kWe})\end{array}$ & $\begin{array}{l}\text { Night } \\
\text { Duty } \\
(\%)\end{array}$ & $\begin{array}{l}\text { SOA PV/ } \\
\text { Battery } \\
\text { Mass } \\
(\mathrm{kg})\end{array}$ & $\begin{array}{l}\text { Advanced } \\
\text { PV/RFC } \\
\text { Mass } \\
(\mathrm{kg})\end{array}$ & $\begin{array}{l}\text { Weight } \\
\text { Saved } \\
\text { at LEO } \\
(\mathrm{kg})\end{array}$ & $\begin{array}{c}\text { HLV } \\
\text { Launches } \\
\text { Saved }\end{array}$ & $\begin{array}{c}\text { Additional } \\
\text { HLVs } \\
\text { Saved } \\
\text { W/SP-100 }\end{array}$ \\
\hline 100 & 100 & 1680000 & 34350 & 7910000 & 87 & 1.6 \\
100 & 20 & 336420 & 7133 & 1580000 & 17.4 & 0.2 \\
\hline
\end{tabular}

compares the system masses for a state-of-the-art photovoltaic generation/battery storage system sized to deliver $100 \mathrm{~kW}$ to a lunar base to that performance projected for an advanced version of such a system. Two cases are considered for the 336-hr lunar night: a $100 \%$ duty cycle and a $20 \%$ duty cycle. Also shown is the mass saved in delivering the advanced system to LEO, along with the resulting number of HLV launches saved, under the assumptions given above. The final column of the table shows the additional number of HLV launches that would be saved by using the SP-100
The program objective in the Surface Power program of Fathfinder is an array specific power of $300 \mathrm{~W} / \mathrm{kg}$ at AMO insolation (solar insolation at 1 A.U.). At present, lightweight photovoltaic arrays have been demonstrated on a Space Shuttle experiment (OAST-1) at $66 \mathrm{~W} / \mathrm{kg}$. A recent design, under development at the Jet Propulsion Laboratory for OAST, was established at $130 \mathrm{~W} / \mathrm{kg}$ (12). This design, the Advanced Photovoltaic Solar Array (APSA), is based on 2-mil thick silicen cells. These two array designs are intended for the zero 
gravity conditions of LEO and GEO (Geosynchronous Earth Orbit). For lunar base applications, the array structure must be rugged enough to withstand the $1 / 6 \mathrm{~g}$ of the lunar surface.

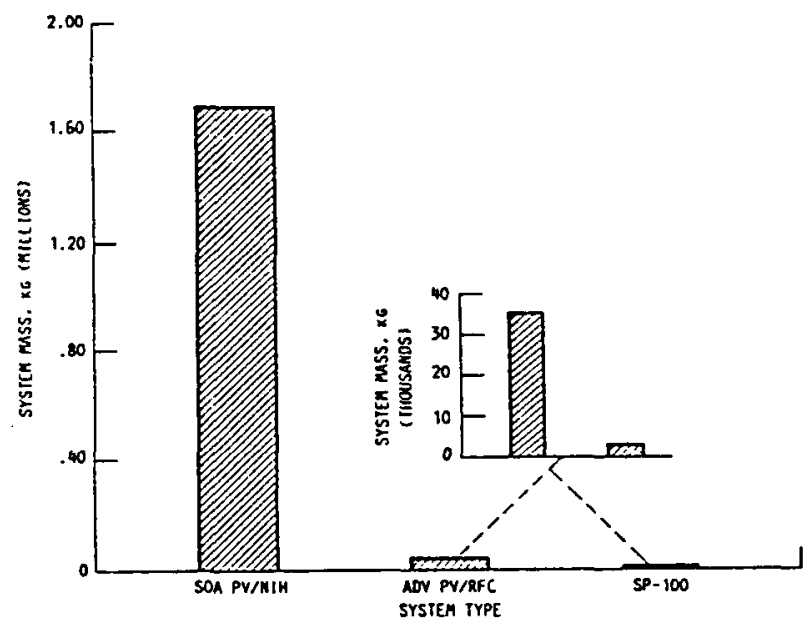

Figure 8. Power Systens Mass Comparison: 1000 kWe Lunar Base, 2-wk Storage

To achieve the $300 \mathrm{~W} / \mathrm{kg}$ specific power goal, two solar cell technologies have been identified for further development. These candidate cell types are ultrathin gallium arsenide (GaAs) and amorphous silicon (a-Si). Table 9 summarizes the technologies to be developed for a lunar base power system and their current performance. GaAs cells are currently manufactured for space use at an efficiency of about $18 \%$, with research devices achieving $21 \%$. However, the current cell is too thick at 200 to $250 \mathrm{~m}$ to give the performance needed for lunar base applications. Fortunately, because it is a direct gap semiconductor, GaAs absorbs all photons available for energy conversion within 3 to $4 \mathrm{~m}$ of the illuminated surface. This allows, unlike crystalline silicon, for an ultrathin, high efficiency cell to be produced. $5.5 \mathrm{~m}$ thick GaAs cells have been fabricated utilizing the CLEFT (Cleaved Lateral Epitaxy for Film Transfer) process (17), a technique in which a single-crystal-thin GaAs layer is grown on a masked GaAs substrate and mechanically removed.
Other processes, such as chemical thinning of the substrate, have also been successfully demonstrated as capable of producing high quality, ultrathin layers and cells (18). Basic research and development in cell interconnectors and cell incorporation into a space compatible blanket will be critical because of the fragile nature of the ultrathin GaAs cells.

Figure 9 shows one approach outlined by NASA toward a $300 \mathrm{~W} / \mathrm{kg}$ zero-g array based on a thin GaAs solar cell. Improvements in the structure and cell interconnector wiring, coupled with the high efficiency, thin GaAs cell, will enable attainment of this performance level. These improvements, as well as the overall design experience gained with zero-g arrays, can be incorporated into the lunar base array structure.

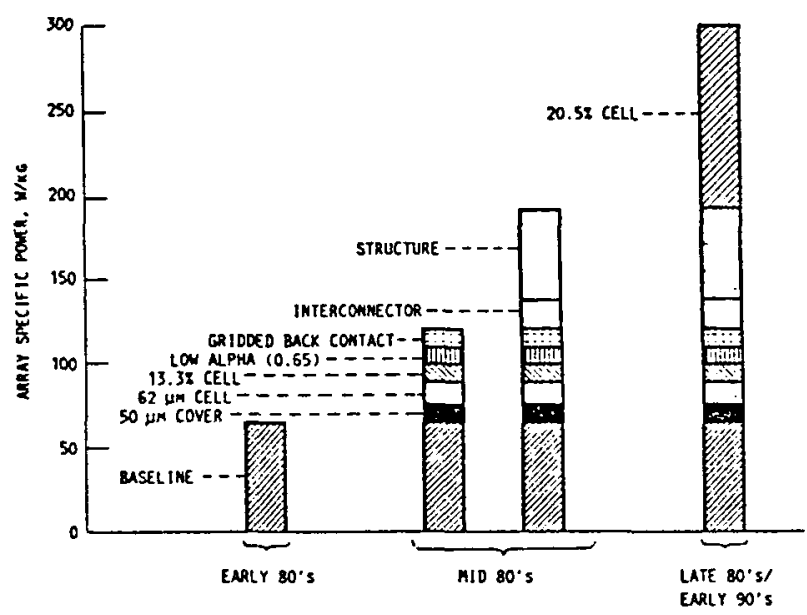

Figure 9. High Performance Solar Array Research and Technology

Anorphous silicon is primarily a terrestrial photovoltaic material. However $9 \%$ space performance has bees measured (14). The electronic structure of amorphous silicon allows for total cell thickness of less than 1 micron and the use of flexible substrates. This is compatible with a very high blanket specific power and low volume storage requirements. Although an extensive terrestrial solar cell manufacturing base already

Table 9. Technology Status and Design Projections

Lunar Base Design

Current Performance

Photovoltaic devices Gallium arsenide Amorphous silicon

Array structure Specific power

Energy storage High pressure gas . $1000 \mathrm{~W}-\mathrm{hr} / \mathrm{kg}$

Regenerative fuel cell $60 \%$ efficiency $\begin{array}{lr}25 \% \text { AMO efficiency } & 21 \% \\ 15 \% \text { AMO efficiency } & 9 \%\end{array}$

$300 \mathrm{~W} / \mathrm{kg}$ (APSA) $66 \mathrm{~W} / \mathrm{kg}($ OASI -1$)$
$300 \mathrm{~W}$-hr/kg (primary fuel cell) $60 \%$ efficiency 


\section{ORIGINAL PAGE IS \\ OF. POOR QUALITY}

exists for a-Si, terrestrial solar cells, several major hurdles must be overcome before it can be considered a viable space cell candidate. Among these are low conversion efficiency and cell performance degradation under constant illumination. In addition, even though some terrestrial modiles are manufactured on flexible, rugged substrates, few of the materials used are compatible with space requirements, necessitating basic studies in blanliet marerials and design.

Research and development on the array structure is also warranted by the need, for the first time, for a space solar array to operate in a continuous gravity field. An APSA wing is pictured in Figure 10, along with the detailed cross-section of its blanket. Its design specific power of $130 \mathrm{~W} / \mathrm{kg}$ is met with $13.5 \%$ efficient, $63 \mathrm{~m}$ thick silicon cells. Replacing the silicon cells with GaAs cells of $25 \%$ ef ficiency, assuming the same blanket mass and eliminating the $10 \%$ mass contingency built into the design yields a specific power of $260 \mathrm{~W} / \mathrm{kg}$, quickly approaching the lunar base goal. This also assumes that a reduced gravity structure will weigh no more than the zero-g APSA structure. The latter may be quite possible, since the APSA structure, blanket box and deployment mechanism constitute more than $50 \%$ of the mass of the entire arzay.

At present only primary fuel cells exist and regenerative cells, which do not limit mission time or power availability by the amount of hydrogen and oxygen that can be carried along, have not yet been demonstrated. The primary focus of RFC research for a lunar base power system will be on fuel cell stack configurations, including oxygen electrode catalysts, thermal and gas management and lightweight, high pressure, robust tank technologies. The principal effect of the 336-hr duration of the lunar night is the requirement for a very large fuel cell reactant mass. Therefore, significant mass gains can be made by reduction of the storage tank mass. Figure 11 illustrates the effect of storage duration on RFC system energy density for several tank types (personal communication with L. H. Thaller of NASA Lewis). For the high pressure gas storage system chosen for the lunat base, the use of filament-wound tanks enables the storage system energy density to approach 1000 W-hr/kg. This can be significantly exeeded by cryogenic reactant storage which at present has application for primary fuel cells only. Feasibility studies being conducted within NASA for using this technology with an RFC on the lunar surface have not yet been completed, but early results look promising.

The question naturally arises concerning the relative impact of ultralightweight array technology versus that of advanced RFC technology for the lunar base. The severe storage requirement ( $336 \mathrm{hr}$ ) means that the batteries comprise over $98 \%$ of the mass of the SOA system in Table 8 . Hence, even if no lightweight array development work occurred, a $97 \%$ reduction in system mass would still be achieved with the RFC technology alone. The answer is that at present there is simply no suitable solar array technology for this application, and given the mass constraint.s of such missions, it is imperative to develop the lightest weight version that is possible. Added to the above are the as yet undefined requirements for minimum stowage volume during earth-lunar transport and for fast, easy deployment and/or ereciability. The situation illustrates the point made at the beginning of the section on NASA mission issues and opportunities. Although total system mass considerations usually predominate, other mission requirements will of ten have as big, if not bigger, an impact on the technology selected for advanced development and flight. In this case, the need for stowability, transportability, and deployability are at least as important as minimum mass.
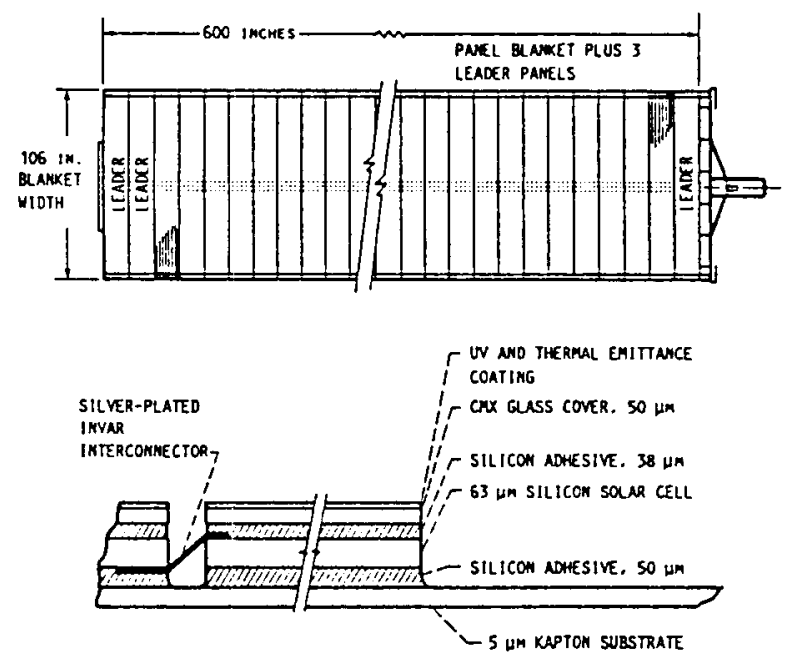

Figure 10. APSA Wing and Blanket

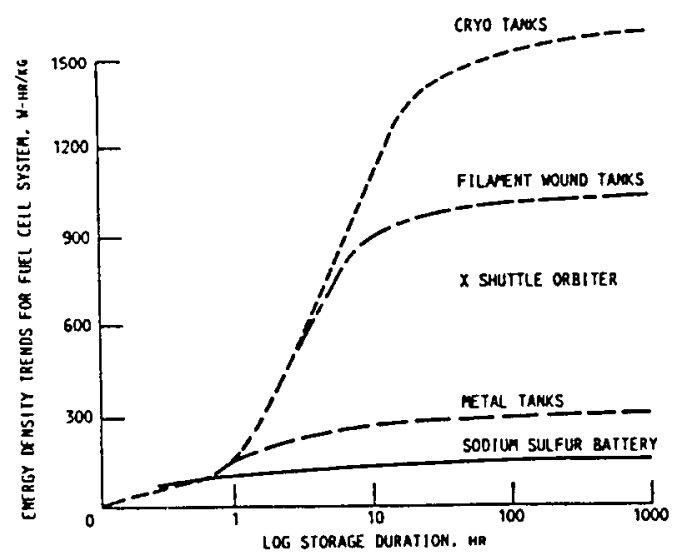

Figure 11. Approximate Energy Density Characteristic of Fuel Cell Systems as a Function of Tank Type and Storage Duration 


\section{SUMMARY - NASA ISSUES AND OPPORTUNITIES}

The intent of the preceding discussion has been only to highlight some of the space power issues currently of high visibility within NASA's advanced planning horizon. There are a number of very legitimate concerns that have not been mentioned that have to do with the more "routine" uses of spacecraft for communication, earth observation, and so on, as well as the myriad of issues associated with development of the solat array for the space station. What has been shown is that there is a growing interest in lightweight concentrator arrays with high levels of radiation resistance for orbital applications, and in a totally new generation of solar array technology for terrestrial-like applications in a nonterrestrial environment. While it is generally true that orbital missions require both minimum mass and minimum area (thereby implying high efficiency), advanced development of photovoltaic power systems for operation on the lunar and/or Martian surface(s) is driven significantly more by other requirements along with minimum mass than by minimum area. This new scenario makes it possible for the terrestrial thin-film technologies to compete effectively with the high-efficiency solar cell technology that has been traditionally pursued in the space program.

\section{ACKNOWLEDGMENTS}

The authors wish to acknowledge the extensive contributions of $W$. M. Zelinsky of the Space Technology Directorate, The Aerospace Corporation for collaboration and studies on space power planning and architecture and $T$. Hershey of the Power Sources Technology and Evaluation Section, The Aerospace Corporation for power source design and modeling.

\section{REFERENCES}

1. Rankine, Maj. Gen. R. R., Jr., Vice Commander, U.S. Air Force Space Division, Banquet Address, Fifth Symposium on Space Nuclear Power Systems, Albuquerque Hilton Eotel, January 1988.

2. Newton, Lt. Col P., "Space Power Options" (Interim Briefing), January 1988.*

3. Borger, W. U. and L. D. Massie, "Space Power Technology for the Twenty-First Century (SPT21)," Proceedings of the IECEC, Pp. 1-7, 3 I July through 5 August 1988.

4. Penn, J. P. and Capt. J. M. Sponable, "Feasibility and Life Cycle Costing Assessment of an Electric Orbital Transfer Vehicle for Navstar Global Positioning System Satellite Delivery," The Aerospace Corporation Report No. TOR-0086(6455-17)-1, June 1986.

5. Zelinsky, W. M., "Space Power Technology Applications," Internal Aerospace Corporation Report to Space Technology Directorate, May 1988.*

6. Weiner, H., "Solar Array Technology," Internal Aerospace Corporation Report, June 1986.*

*Not available outside The Aerospace Corporation.
7. Kurland, R. M. and P. Stella, "Advanced Photovoltaic Solar Array Development," Proceedings of the Space Photovoltaic Research and Iechnology Workshop, 19-21 April 1988.

8. Papula, P., GE Aerospace communicated information based on Series 5000 Design Solar Array, July 1988.

9. Tracy, J. and J. Wise, "Space Solar Panel Performance Comparisons for Advanced GaAs and Si Solar Cells," Proceedings of the 20th IEEE Photovoltaic Special ists Conference, 26-30 September 1988.

10. Gee, J. M., "A Comparison of Different Module Configurations for Multi-Band-Gap Solar Cells," Solar Cells, 24 (1988) 147.

11. Hershey, T. L. and H. Weiner, "Power System Design Analysis Computer Program," Proceedings of the IECEC, PP. 529-535, 31 July through 5 August 1988 .

12. Scott-Monck, J. and P.Stella, "Advanced Photovoltaic Solar Array Program - A Preliminary Assessment," Advancing Toward Technology Breakout in Energy Conversion, 2lst IECEC, Vol. 3, Am. Chemical Society, Washington, D.C., Pp. 1458-1461 (1986).

13. Weinberg, I., C. K. Swartz, R. E. Hard, Jr., and R. L. Statler, "Radiation and Temperature Effects in GaAs, InP and Silicon Solar Cells," Proc. of the 19th IEEE PUSC, p. 19 (1986).

14. Hanak, J. J., Englade Chen, C. Fulton, and A. Myat t, Energy Conversion Devices, Inc., and J. R. Woodyard, Wayne State University, "Ultralight Amorphous Silicon Alloy Photovoltaic Modules for Space Applications," Proc. of the 8 th Conference on Space Photovoltaic Research and Technology, NASA CP2475, p. 19 (L986).

15. Stanbery, B. J., J. E. Avery, R. M. Burgess, W. S. Chen, W. E. Devaney, D. H. Doyle, R. A. Mickelsen, R. W. McCell and, B. D. King, R. P. Gale, and J. C. C. Fan, "Thin Film Tandem GaAs/CuInSe 2 Solar Celis for Space Power Applications," Proc. of the $19 \mathrm{th}$ IEEE PVSC, P. 280 (1987).

16. Brinker, D. J., R. E. Hart, and I. Weinberg, "InP Homojunction Solar Cell Performance on the LIPS III Flight Experiment," Proc. of the 20th IEEE PVSC, to be published.

17. Fan, J. C. C., R. W. McCelland, and B. D. King, "GaAs Cleft Solar Cells for Space Applications," Proc. of the 17 th Photovoltaic Specialists Conf., IEEE, Piscatawny, NJ, pp. 31-35 (1984).

18. Loo, R. Y., G. S. Kamath, and R. C. Knechtli, "Thin GaAs Solar Cells," Proc. of the 17th IEEE Photovoltaics Specialists Conf., p. 46 (1984). 


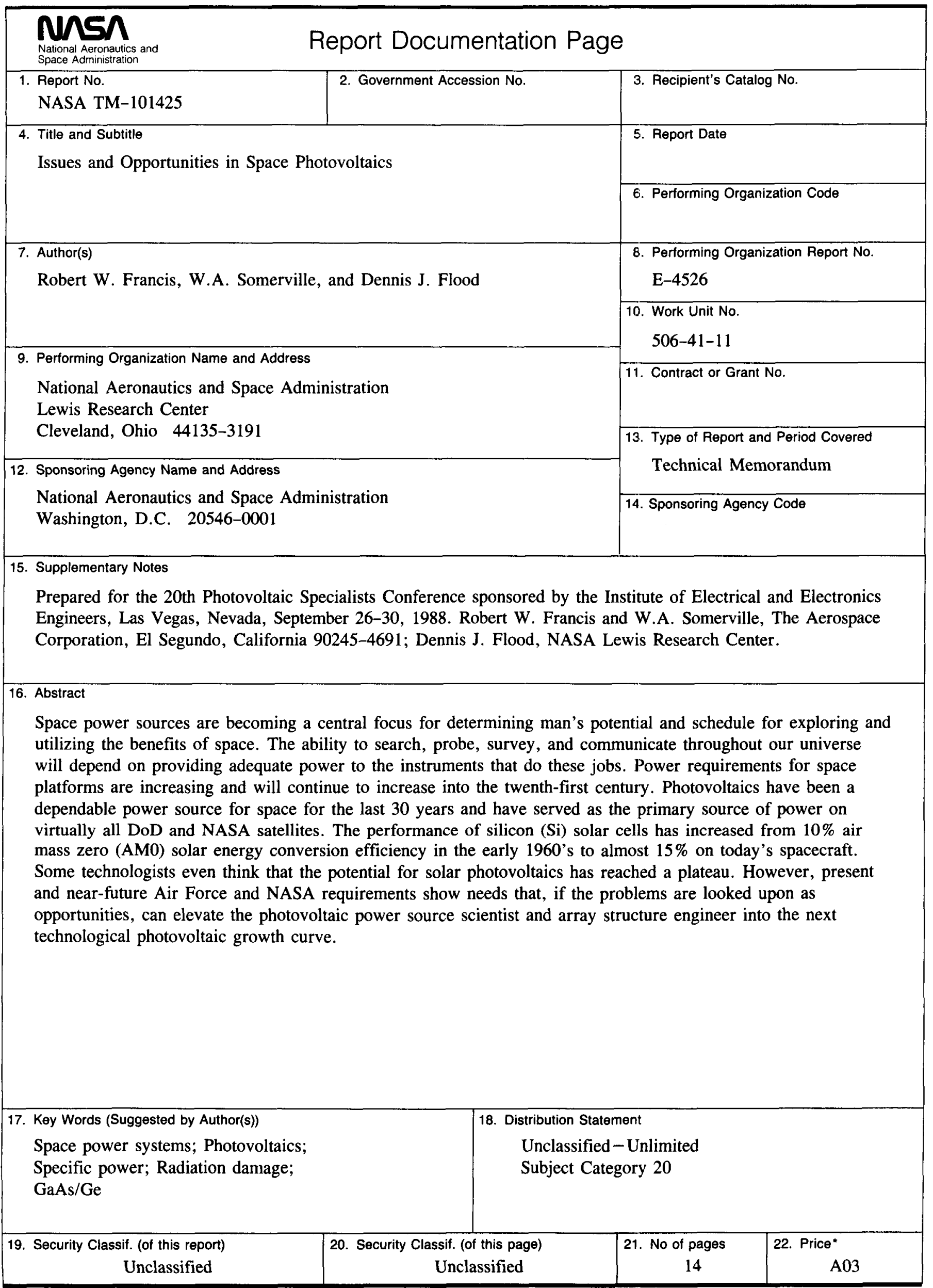

NASA FORM 1626 OCT $86 \quad$ *For sale by the National Technical Information Service, Springfield, Virginia 22161 